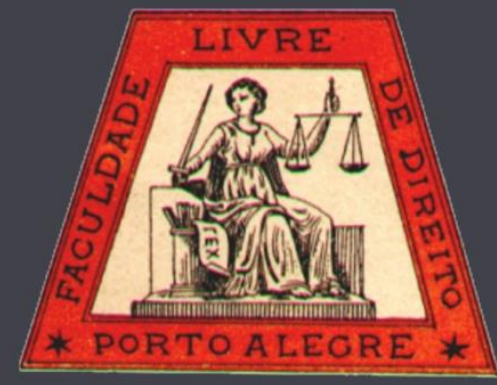

\title{
História do Direito Administrativo no Brasil (1937-1964): o debate em torno das delegações legislativas
}

The history of the Administrative Law in Brazil (1937-1964): the debate about legislative delegation

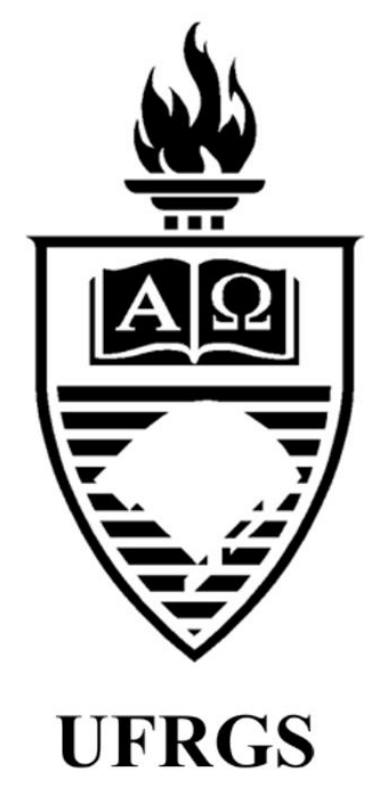

Mauricio Costa Mesurini

Universidade Federal de Santa Catarina

Revista da Faculdade de Direito da UFRGS

ISSN: 0104-6594 Site http://seer.ufrgs.br/revfacdir

Faculdade de Direito da UFRGS - Rua Riachuelo, 1317 - Centro - Porto Alegre - RS - Brasil

CEP - 90010-271 - Telefone: +55 5133083118 - Site http://www.ufrgs.br/direito/ 


\title{
História do Direito Administrativo no Brasil (1937-1964): o debate em torno das delegações legislativas
}

The history of the Administrative Law in Brazil (1937-1964): the debate about legislative delegation

\author{
Mauricio Costa Mesurini*
}

\section{REFERÊNCIA}

MESURINI, Mauricio Costa. História do Direito Administrativo no Brasil (1937-1964): o debate em torno das delegações legislativas. Revista da Faculdade de Direito da UFRGS, Porto Alegre, n. 35, p. 59-84, dez. 2016.

\section{RESUMO}

Trata-se de um trabalho sobre história do Direito Administrativo no Brasil, notadamente no período de 1937 a 1964. O objetivo é mostrar alguns aspectos da trajetória do campo, em especial as transformações favorecidas pela tendência modernizadora, entre elas, o debate em torno das delegações legislativas, um tema que se desenvolveu na doutrina a partir e à margem das disposições constitucionais da época. É inegável a importância da lei para o direito público moderno. Mas o que é a lei? Quem tem o poder de confeccioná-la? " $O$ governo das leis" em substituição ao "governo dos homens", em verdade uma tautologia, encobre o problema sobre a fonte de onde emanam as leis. Assim sendo, mesmo em um Estado de Direito, a disputa políticojurídica permanece latente e continua em jogo a definição de quem são os "senhores" da legislação. O artigo investiga o debate jurídico em torno das delegações legislativas abordando quatro juristas da época: Francisco Campos, Victor Nunes Leal, Bilac Pinto e Themistocles Cavalcanti.

\section{PALAVRAS-CHAVE}

Direito Administrativo. Direito Constitucional. Delegações legislativas. Separação de poderes.

\begin{abstract}
This paper is a study on the history of administrative law in Brazil, notably in the period 1937-1964. The purpose is to present some aspects of the development of this field of study, especially the changes favored by the modernization process through which Brazil has passed, such as the debate about legislative delegation, a theme that was developed in the legal doctrine from and beyond the constitutional arrangement of the period. It is undeniable the importance of the legislation to modern public law. But what is legislation? Who has the power to make it? The "rule of law" replacing the "government of men", in fact a tautology, conceals the problem of the source from where the law emanates. Therefore, even in the bases of the rule of law, the legal-political dispute remains latent, and the definition about who establishes the law remains open. More specifically, the paper analyzes the debate about legislative delegation in Brazil by four legal experts of the period: Francisco Campos, Victor Nunes Leal, Bilac Pinto and Themistocles Cavalcanti.
\end{abstract}

\section{KEYWORDS}

Administrative law. Constitutional law. Legislative delegation. Separation of powers.

\section{SUMÁRIO}

Introdução. 1. O contexto das fontes. 2. O Direito Administrativo como um saber histórico. 3. Intervenção do Estado e modernização do Direito. 4. Delegações legislativas. 4.1 Francisco Campos. 4.2 Victor Nunes Leal. 4.3 Olavo Bilac Pinto. 4.4 Themistocles Brandão Cavalcanti. Conclusão. Referências.

\footnotetext{
* Doutor em História do Direito pela Universidade Federal de Santa Catarina - UFSC, 2016. Mestre em 2008 e graduado em 2005 pela Direito Público Universidade Federal de Santa Catarina - UFSC. Professor de Direito Administrativo da Faculdade Cenecista de Joinville
} 


\section{INTRODUÇÃO}

A partir da Revolução de 1930 o âmbito de intervenção estatal no Brasil foi ampliado substancialmente, aumentando as relações entre política e economia. As transformações operadas nas diferentes esferas sociais exigiram do mundo jurídico novas racionalizações. Tendo em vista a proximidade com a política e a economia, vários foram os impactos no direito constitucional e administrativo, que passaram a ser revistos para além das suas raízes teóricas liberais. Dessa forma, torna-se relevante investigar as transformações operadas nestes ramos do direito público a partir das diferentes fontes do direito, entre elas, a doutrina juspublicista.

O que se pretende demonstrar é que, com a tendência à intervenção vista por muitos como "necessária", a economia passou a integrar mais abertamente a política, potencializando-se a dominação técnica, o que se refletiu diretamente na dinâmica da separação dos poderes e da própria democracia, já que na medida em que os espaços deliberativos foram enfraquecidos, fortaleceram-se os órgãos técnicos. A política ganhou um viés de ciência, restringindo a participação dos "leigos". O Poder Executivo foi fortalecido, tanto em sua estrutura como nas suas competências e houve um deslocamento do poder normativo em direção ao Executivo. Estas transformações se operaram muitas vezes à margem dos textos constitucionais e com lastro na doutrina jurídica produzida na época.

\section{CONTEXTO DAS FONTES}

O presente trabalho se circunscreve no campo da história das ideias jurídicas. Essa atenção à abordagem histórica não se dá pela curiosidade diletante em busca de um "verniz de erudição", como leciona Antonio Carlos Wolkmer (2003), mas, pelo objetivo de investigar as raízes conceituais e institucionais do direito e da dogmática jurídica; não para justificar o direito presente ou as ações do passado, mas para resgatar racionalidades, linguagens e personagens muitas vezes perdidos no tempo ou relidos e até mesmo "naturalizados" com intuitos legitimatórios. Enfim, como leciona António Hespanha, para criticar o acrítico dogmático. ${ }^{1}$

A tarefa hermenêutica do historiador do direito deve ser precedida de cautelas, tais como a inserção das fontes no horizonte cultural em que elas surgiram e operaram, bem como o esforço em evitar uma interpretação anacrônica pautada pela experiência jurídica própria do historiador. Enfim, cabe interpretar as fontes a partir dos seus próprios pressupostos e vinculada ao seu contexto cultural, "enterderla como solución a um problema de ordenación planteado en su momento" (STOLLEIS, 2009, p. 28). ${ }^{2}$

Quanto aos ramos do direito administrativo e constitucional, os manuais brasileiros costumam passar ao largo do tema histórico da disciplina. ${ }^{3}$ Quando assim não o fazem, dedicam

1 “A opinião adoptada neste curso é a de que a história do direito é, de facto, um saber formativo; mas de uma maneira que é diferente daquela em que o são a maioria das disciplinas dogmáticas que constituem os cursos jurídicos. Enquanto que as últimas visam criar certezas acerca do direito vigente, a missão da história do direito é antes a de problematizar o pressuposto implícito e acrítico das disciplinas dogmáticas, ou seja, o de que o direito dos nossos dias é o racional, o necessário, o definitivo. [...] as soluções jurídicas são sempre contingentes em relação a um dado envolvimento (ou ambiente). São, nesse sentido, sempre locais" (HESPANHA, 2005, p. 21).

2 Para Stolleis, "el pasado sigue siendo 'en quanto tal' irrecuperable, no existe um acesso directo a él. Sigue siendo visible, pero, como si estuviera trás um vidrio translúcido, con contornos siempre más o menos difuminados" (STOLLEIS, 2009, p. 20). Sobre uma discussão a respeito da metodologia da história do direito, vide (STOLLEIS, 2009, p. 03-31).

${ }^{3}$ Entre os manuais, Oswaldo Bandeira de Mello dedica uma análise da história nacional da disciplina, mas adota uma metodologia linear e progressista, sem abordar as rupturas e influências políticas e econômicas. Vide BANDEIRA DE MELLO, 2007. Quanto ao direito constitucional, temos a obra de Paulo Bonavides e Paes de Andrade. Trata-se de um bom livro para introduzir a 
algum capítulo inicial para traçar um "escorso" histórico geralmente tranquilo, linear e progressivo, na maioria das vezes com propósitos de justificar a "maturidade" dos conceitos e institutos da atualidade, o que acaba por empobrecer os debates jurídicos e políticos do passado. Até parece que tudo se deu por uma simples e tranquila "importação" de conceitos e institutos estrangeiros, mediante procedimentos técnicos e alheios às escolhas políticas e econômicas. Enquanto o país passava por conflitos (inclusive levantes armados) que conduziram a sensíveis rupturas políticas e econômicas, o direito pareceria, assim, reinar soberano em seu universo simbólico tecnicista.

Ocorre que a história do direito não é tranquila como se quer fazer crer. Como um Janus, o direito pode aparentar na dogmática a sua face serena, porém, mergulhado que está em meio às transformações políticas e econômicas, revela sua outra face atormentada. ${ }^{4}$

Portanto, a história do direito no Brasil é um tema necessário. Não é incomum encontrar nos manuais jurídicos, conceitos e instituições que parecem descolados de realidade e de significado (v.g. atos de império e atos de gestão; interesse público primário e secundário, etc.), regimes jurídicos até hoje de difícil

pesquisa sobre história constitucional do Brasil, entretanto, como o ponto de referência dos autores foi a Constituição da República Federativa do Brasil de 1988, muitos dos debates jurídicos envolvendo as constituições pretéritas, ou são ignorados ou são analisados à sombra da "Constituição cidadã”. Vide BONAVIDES; ANDRADE, 2004. Também, é forçoso citar a obra organizada pela editora do Senado Federal ("Coleção Constituições Brasileiras", sete volumes). Embora sintéticos, os volumes procuram trazer uma análise histórica mais voltada para o passado, inclusive trazendo textos de autores da época.

${ }^{4}$ Essa analogia à divindade pagã foi adaptada a partir de BURDEAU, 2005. Sobre Janus, “[...] divindade latina que nunca foi admitida pelos gregos. Organizador e regulador do mundo, Jano representa a transição e a passagem; é por isso que a porta, assim como um dos meses do ano (janeiro) lhe eram consagrados. [...] dão-se-lhe dois rostos porque conhece o passado e o futuro. O seu templo só permanecia aberto durante a guerra, e fechava-se durante a paz, [...]" (MÉNARD, 1991, p. 31). compreensão e que, não raro, são levados à discussão nos tribunais (v.g. regimes das autarquias, fundações e empresas estatais) e instituições "vendidas" como grandes novidades (v.g. agências reguladoras e toda sorte de argumentos para justificar seu "poder normativo estendido”). ${ }^{5}$ Por isso, a análise histórica também pode contribuir para a melhor compreensão do direito atual.

O período estudado neste artigo é de grande importância para a compreensão da construção da estatalidade nacional. Gilberto Bercovici afirma que a construção do Estado nacional nos anos pós-30 se deu, em essência, a partir do Poder Executivo. Da mesma forma, segundo o autor, o modelo interventor foi concebido à margem do plano constitucional, o que, para ele, representou um divórcio entre Estado e Constituição, ou, como o professor paulistano diz, "um diálogo entre ausentes". Conclui que a Constituição não foi a referência de atuação do Estado interventor, que se deu predominantemente no âmbito do direito administrativo e econômico. ${ }^{6}$ Alguns argumentos utilizados: “delegation with
standards" constitucional" (Gilmar Mendes e Tércio Sampaio Ferraz Junior); "delegação instrumental” (Marcos Villela Souto), etc. Inclusive esses foram os argumentos centrais nas ADIns 3.090, 3.100 e 3.101 que questionavam as medidas provisórias que tratavam sobre o "Novo Modelo" de Estado, todas da lavra do Min. Gilmar Mendes, muito simpático ao tema da "mutação constitucional". Sobre o tema vide ARAGÃO (Org.), 2011 e TOLMASQUIN, 2011.

${ }^{6}$ Inclusive Bercovici cita em nota a obra de Themistocles Cavalcanti (Instituições de Direito Administrativo Brasileiro - 1936) como uma referência para ilustrar essa conclusão. BERCOVICI, [s.d.]. Robertônio Pessoa, também baseado no texto de Bercovici, afirma que foi na era Vargas que se estruturou o direito administrativo brasileiro (2009, p. 157). Entendo que tal afirmação é um exagero e incorre em uma análise que despreza os diferentes contextos históricos em que a disciplina se formou, como se não existisse direito administrativo brasileiro antes de 1930, como se as obras de Uruguai, Viveiros de Castro, Ruy Barbosa, Aurelino Leal, entre outros, não tivessem tido qualquer importância. $\mathrm{O}$ que se deu na Era Vargas foi uma reestruturação do direito administrativo a partir de um novo modelo de Estado que 
As transformações sociais do período, principalmente no tocante a um Estado de perfil mais interventor, ${ }^{7}$ exigirão uma nova, senão reformulada base jurídica que repercutirá consideravelmente no direito público. Nesse sentido, quanto mais a economia se torna a dimensão dominante do Estado ante o desdobramento da revolução industrial, mais surge a necessidade de se pensar sobre um campo especial do direito administrativo, permeado pelo fator econômico. (STOLLEIS, 2004, p. 226) ${ }^{8}$

O momento histórico caracterizava-se, entre outros aspectos, por um embate político desenvolvido nos meios intelectuais, uma disputa conceitual geralmente caracterizada por dicotomias. Entre esses conceitos encontra-se o significado a ser dado ao intervencionismo estatal..$^{9} \mathrm{O}$ intervencionismo, além de atrelado à

se pretendia construir, reestruturação que não se deu "do nada", mas a partir de releituras do direito preexistente. Vide GUANDALINI, 2011.

${ }^{7}$ É importante mencionar que já na $1^{\mathrm{a}}$ República a ideia de intervenção estatal não é estranha ante a existência de "ilhas de intervenção" do Estado (SEELAENDER, Airton. Conferência no I Congresso Brasileiro de História do Direito - IBHD, Florianópolis/SC). Não obstante, o modelo interventor de Estado ganha corpo e estrutura nos anos pós-1930 (VENÂNCIO FILHO, 1979, passim). Na $1^{\text {a }}$ República havia um intervencionismo estatal voltado ao setor agrário exportador, nomeadamente, o café. Porém, não havia uma intervenção em favor da indústria, salvo um incipiente fomento ao setor têxtil (SKIDMORE, 2012, p. 74-75). Também sobre o tema, vide DINIZ, 1978. DRAIBE, 2004.

8 Sobre as transformações no direito administrativo, forçadas a partir da era industrial, vide STOLLEIS, Michael, abril-junho 1993. Também, vide HESPANHA, 2005, p. 119-159. Também, sobre os impactos administrativos ante as transformações políticas e econômicas, vide ESTORNINHO, 2009; METZLER, 1935.

9 A imprecisão terminológica sobre o significado do intervencionismo estatal não era uma exclusividade brasileira. Leciona Venâncio Filho que "A própria incerteza de terminologia em definir o fenômeno da intervenção do Estado no domínio econômico denota a falta de sistemática dessa intervenção. Nas palavras de Laufenburger, 'como mostrou Saitzew na sua contribuição aos Estudos Fleiner, a expressão intervencionismo cobre tôda uma série de expressões tais como: economia dirigida, controlada ou organizada, capitalismo regulamentado ou ideia de modernização, aparece como um dos conceitos-chave, pois funcionava como um indutor na concepção e/ou releitura de outros conceitos a ele atrelados.

A partir da década de 1930 - quando a Revolução foi um mecanismo para "impor" a transformação -, o país passa pelo grande desafio de renovar sua base produtiva (política de substituição de importações), em grande parte ocasionada pela crise econômica de 1929, que abalou significativamente o modelo agrárioexportador e financeiro. ${ }^{10}$ Também, vale destacar o fenômeno da urbanização. Essa renovação econômica e social passava necessariamente por uma reestruturação política e, principalmente, administrativa. Política, economia e direito passaram por transformações relevantes após a Revolução de 1930, que forçaram mudanças de racionalidade interna, bem como fizeram com que as esferas sociais se relacionassem mais intensamente, gerando favorecimentos por afinidade eletiva. (CASTRO; MESURINI, 2007, p. 04).

A alteração no perfil do Estado após as duas Grandes Guerras será notada em vários países. Uma nova proposta de Estado, agora mais voltada à intervenção econômica e social, não é, portanto, um fenômeno privativo do Brasil (STOLLEIS, 2004, p. 139 e ss.). Como um país de recepção e adaptação de ideias, nesse período, muitas doutrinas e ideologias chegam ao Brasil e serão assimiladas e adaptadas por diversos intelectuais da época, muitos deles pessoas afetas às ciências jurídicas. ${ }^{11}$

planificado, neo-capitalismo, neo-mercantilismo, reformismo social, estatismo, corporativismo, etc. [...] a palavra intervencionismo parece implicar um fato positivo, uma ação construtiva do Estado. [...]."” (1968, p. 11).

${ }^{10}$ Vide FURTADO, 1971.

${ }^{11}$ Os autores mais emblemáticos do período são Oliveira Vianna, Francisco Campos e Azevedo Amaral. "O apoio fundamentado de jovens intelectuais, em geral oriundos da classe média, ajudou a dar a cada estágio uma aura de legitimidade a um líder que não era dado a desculpas ideológicas. Essa legitimidade intelectual era importante para muitos brasileiros que aprovavam em silêncio as 
Esses impactos no modelo administrativo, forçados pela tendência intervencionista, repercutirão nos contornos do direito público, nomeadamente no direito administrativo. Enquanto no Estado Liberal as tarefas estatais apontavam para uma "intervenção pontual $e$ esporádica da Administração", contentando-se com um "laissez faire"; no Estado Social houve a ampliação da atuação administrativa onde o Estado se propôs a "faire elle-même". (ESTORNINHO, 2009, p. 35-40; GUTIÉRREZ, 2004). Portanto, estabeleceu-se uma necessária relação entre Estado, administração e direito administrativo. $\mathrm{O}$ direito público passará, consequentemente, por uma releitura em seus conceitos essenciais, bem como por uma formulação de novos institutos a fim de enfrentar o desafio de fornecer mecanismos que possibilitassem uma administração ativa.

\section{O DIREITO ADMINISTRATIVO COMO UM SABER HISTÓRICO}

O direito é um saber historicamente localizado (HESPANHA; FONSECA). Não seria diferente com o direito administrativo, ramo tão sensível às mudanças políticas, sociais e econômicas. Entretanto, não se pretende fundir direito com história, ou seja, quando se diz que o direito administrativo é um saber histórico não se está a afirmar que sua autonomia cientifica esteja diluída na historiografia, mas sim que os conceitos jurídicos possuem um "DNA histórico", ou seja, se constroem (e são relidos), necessariamente, a partir de pressupostos e referenciais teóricos localizados historicamente. $^{12}$

políticas de Vargas, mas gostariam de ouvir uma exposição de motivos para as ações do presidente" (SKIDMORE, 2010, p. 70).

12 Sobre a faceta histórica do direito público, especialmente a teia de relações entre direito e política, "Na história do direito público devem figurar, ainda, os vínculos entre as questões ditas de direito público e o contexto político em que ocorreram. As implicações
Segundo Carl Schmitt, o direito administrativo nasceu sob as asas do Estado de Direito liberal. No anterior Estado de polícia, pautado pela razão de Estado absolutista, era impensável a existência do direito administrativo, que pressupõe limites jurídicos ao poder. Daí que o modelo liberal forneceu as condições de possibilidade para o florescimento do direito administrativo, tais como a separação dos poderes, os limites jurídicos à administração e a proteção da liberdade individual (FORSTHOFF, 1958, p. 71).

Não sem razão o objeto central do direito administrativo fora a doutrina do ato administrativo, que uma vez extraída da teoria civilista do ato jurídico fora "filtrada" a partir da preocupação em se criar um mecanismo que conjugasse a atuação mínima da administração, com a proteção máxima dos direitos individuais (ESTORNINHO, 2009, p. 33).

Para Gustav Radbruch, o direito administrativo surge como um ramo jurídico de proteção dos indivíduos, eis que quando as atividades administrativas eram conduzidas unicamente pela conveniência política, sem qualquer barreira jurídica, havia uma técnica administrativa e não um direito administrativo. Assim sendo, o direito administrativo passou a existir apenas quando o interesse individual, concebido enquanto um direito subjetivo, fora colocado no caminho do interesse público, possibilitando a reciprocidade de direitos e deveres que compõe a natureza própria do direito (RADBRUCH, 1999, p. 164-165).

políticas das grandes questões de direito público podem ser muitas vezes percebidas, nem que seja ao menos em parteem nenhum outro campo jurídico parece tão fina aquela máscara jurídica que, segundo Kelsen, cobriria a 'cabeça de górgona do Poder'. Na medida em que as fontes o permitam, devem ser identificados, portanto, os interesses em jogo e os grupos sociais envolvidos (estamentos, classes, redes clientelares, cliques, etc.). Essa vinculação ao contexto político também se faz necessária em virtude da permeabilidade- de grau historicamente variável- do direito público às teorias e conceitos oriundos do discurso político stricto sensu." (SEELAENDER, 2007, p. 278). 
$\mathrm{Na}$ França, um direito administrativo autônomo configurou-se após a Revolução Francesa, sedimentando-se sobre as estruturas administrativas do Ancien Régime. O Conselho de Estado francês foi de capital importância para a formação e o aperfeiçoamento desse novo ramo jurídico. Após a Revolução, era preciso ter um ramo jurídico que disciplinasse especificamente as relações entre Estado e indivíduo; este, agora, concebido como um sujeito de direitos e aquele, embora soberano, como um garantidor desses direitos. O Conselho de Estado foi o responsável inicial pela racionalização interna do direito administrativo na medida em que facilitou a construção de um regime jurídico próprio à administração, a partir e além dos conceitos do direito privado. O contencioso administrativo justificava-se, em síntese, a partir de três argumentos. Os juízes "comuns" não eram aptos a enfrentar os novos desafios jurídicos, pois além de não conhecerem da matéria eram muito apegados ao direito privado. Tais juízes, caracteristicamente conservadores, ainda possuíam sólidos vínculos com o Antigo Regime. Por fim, a própria teoria liberal da separação dos poderes explicava aquela jurisdição extravagante, eis que julgar a administração era uma maneira de administrar (FORSTHOFF, 1958, p. 86; BURDEAU, 1995, p. 114-121).

Tocqueville, por sua vez, ofertou críticas ao modelo francês, dizendo que se formou uma administração demasiadamente centralizada, que um tribunal administrativo não era a instância adequada para julgar a própria administração e que o direito administrativo fora concebido a partir de uma prática administrativa. ${ }^{13}$

\footnotetext{
${ }^{13}$ Entretanto, há de se mitigar a crítica de Tocqueville ao sistema francês, haja vista seu deslumbramento em relação ao modelo político e administrativo norte-americano. Vide TOCQUEVILLE, 1866. p. 66-75. Também, uma interessante análise da soberania popular nas sociedades modernas a partir da visão liberal de Tocqueville, bem como algumas impressões do autor sobre o direito
} administrativo francês, vide GONÇALVES, 2010.
A contraposição entre Estado e Sociedade civil condicionou as concepções centrais do direito administrativo liberal do século XIX, vigente até o fim do primeiro pós-guerra. Depois disso, ante a diversificação das tarefas estatais, na Alemanha, p.ex., houve uma revisão geral dos pressupostos metodológicos do direito público. O direito administrativo passou a ser um sistema de controle e direção do Estado, exigindo a superação daquele modelo concebido à luz do liberalismo, sob um viés marcadamente abstencionista. Sobretudo após a ascensão do regime nacional-socialista, frente à inexistência de uma ordem constitucional, o direito administrativo passou a ser o único espaço para a aplicação dos métodos da tradição do direito público, que foram repensados para além do Estado de Direito liberal e seu formalismo, e com vistas a um funcionamento efetivo da administração pública.

Para Arnold Köttgen, na proposta liberal, as formas não eram fins em si mesmos, mas serviam para demarcar as fronteiras entre Estado e sociedade civil, porém, elas já estavam superadas. Logo, eram assimiladas como uma "relíquia" liberal (apud STOLLEIS, 2004, p. 335; GUTIERRÉZ, 2004, p. 410). A despeito das consequências negativas do afastamento do formalismo liberal, Stolleis destaca que houve um impulso modernizador para o direito administrativo, voltado a um Estado de perfil prestacional e interventor. (1993, p. 7). ${ }^{14}$

Registrando um descompasso do direito constitucional com a administração moderna (voltada à atividade administrativa conformadora), Forsthoff defende o protagonismo do Direito Administrativo em absorver em seu interior as relações entre o indivíduo e a administração, a partir de uma forma jurídica para além do tradicional "Estado de Direito Burguês". A função conformadora da

\footnotetext{
${ }^{14}$ Sobre a história do direito administrativo na França, vide
} BURDEAU, 2001. 
administração impunha um Estado ativo, provedor dos bens existenciais (Daseinvorsorge), ${ }^{15}$ redundando em uma necessária releitura dos conceitos essenciais, tais como o ato administrativo, o poder normativo, o poder discricionário e os serviços públicos, com vistas a uma ampliação das competências administrativas nesta função de conformação social (1958, p. 108-117). ${ }^{16}$

Por fim, registrando a dimensão histórica do Direito Administrativo, também se pode notar a alteração funcional e estrutural do campo nos EUA, notadamente nos anos pós-New Deal quase que se confundindo como o "direito das agencias reguladoras" -, resultado de visões

\footnotetext{
${ }^{15}$ Sintetizando o conceito de Daseinsvorsorge, trata-se de uma finalidade estatal geral voltada à assistência vital ou às prestações vitais, levando ao conceito de leistende Verwaltung, traduzido na administração que abastece, que provém, que atua diretamente a proporcionar bens e serviços aos cidadãos. (BAQUER, 2015, p. XXXII). Baquer sublinha a "aformalidade" de tais conceitos, sobretudo do primeiro, consistindo na sua relatividade, haja vista a própria variação das prestações vitais (BAQUER, 2015, p. XLII).

16 "En el campo de la actividad administrativa conformadora nos hallamos, pues, ante nuevas estructuras jurídicas, todavía, en desarrollo, que no pueden ser aprehendidas plenamente con los métodos tradicionales de la ciencia del Derecho Administrativo. Y lo mismo puede decirse de los médios de acción soberana de que se sirve la administración en su función conformadora. [...] La Administración conformadora trabaja bajo condiciones que escapan en absoluto la técnica de la garantía de la liberdad y del control jurídico producida por el Estado de Derecho burgués. [...] El individuo hoy no se enfrenta con la Administración independientemente, sino en situación de dependencia. El individuo necessita para su vida diária de los servicios de la Administración, su capacidad de trabajo se halla en gran medida bajo el poder de disposición del Estado, y como sujeto económico está inserto en el sistema de planificación estatal. [...] En uma palabra: toda la estructura tradicional del Estado de Derecho ha perdido en gran parte su vigencia. El moderno Derecho constitucional no tiene en cuenta, sin embargo, este hecho, si no que permanece aferrado a las formas tradicionales. De aquí proviene el problema - en el fondo insolubre - de dar a las relaciones del individuo con la Administración dentro del Derecho administrativo actual una forma jurídica adecuada a um Estado de Derecho." (FORSTHOFF, 1958, p. 115; 116; 117). Sobre as alterações no conceito de Estado de Direito em diferentes épocas e trabalhos do autor, vide FORSTHOFF, 2015.
}

políticas que sublinharam a importância da administração em sua faceta reguladora, burocrática e "julgadora" (WHITE, 2000).

\section{INTERVENÇÃO DO ESTADO E MODERNIZAÇÃO DO DIREITO}

Nos anos pós-1930 se fortalecem as tendências de que as estruturas "atrasadas" da "República Velha" deveriam ser deixadas no passado. Esse passado só poderia ser superado através da mão visível do Estado, já que a sociedade civil, por si, não seria capaz de fazêlo.

Segundo Lynch (2015, p. 04), a cultura política brasileira tem a modernização como um dos seus temas característicos. Partindo do pressuposto de uma realidade nacional atrasada, a modernização era um imperativo a fim de diminuir a distância em relação aos países tidos como padrão de avanço e civilização, em especial a Inglaterra, a França e os Estados Unidos. Os diferentes assuntos eram valorados $\mathrm{e}$ selecionados a partir do critério modernizador e as instituições e os conceitos eram importados. ${ }^{17}$

Ocorre que, se nesses países de referência as instituições deveriam acompanhar o desenvolvimento da sociedade, nos países atrasados dava-se o contrário. Aqui, as instituições não deveriam refletir o estado social (que era atrasado), mas sim agir sobre ele a ponto de modificá-lo, aproximando-o dos ideais de progresso ( $\mathrm{LYNCH}, 2015$, p. 04; 06). Por isso, os conceitos deveriam funcionar como indutores do desenvolvimento.

O discurso modernizador deveria ser conduzido pela intelectualidade, vista como a expressão lúcida da sociedade, "prenunciadores

17 Sobre a elite intelectual no Brasil, os "homens de pensamento", Oliveira Vianna dizia que viviam "duas culturas: uma - a do seu povo, que lhes forma o subconsciente coletivo; outra - a européia ou norteamericana, que lhes dá as idéias, as diretrizes de pensamento, os paradigmas constitucionais, os critérios do julgamento político.” (apud SILVA, 1998, pp. 138-139). 
das grandes mudanças históricas e arautos da renovação nacional." Os intelectuais funcionavam como vozes intermediárias, vistos como capazes de captar e exprimir a vontade popular. (VELLOSO, apud LOSSO, 2006, p. 24)

Entre outros aspectos, a ideia de modernização trazia em seu bojo o que Bolivar Lamounier denominou como "ideologia de Estado", sobretudo o "objetivismo tecnocrático". 18 Quanto ao "objetivismo tecnocrático", consistia no mito da racionalidade técnica em substituição à irracionalidade política. Ricardo Virgilino da Silva também destaca o caráter tecnocrático e o apelo à ciência e à técnica como princípios de legitimação a partir da hipertrofia e do protagonismo do Poder Executivo, composto por uma "elite científica". ${ }^{19}$ Conforme Vianna, "em toda a parte a competência técnica vai substituindo a competência parlamentar." (apud SILVA, 1998, p. 129)

Se a política passou a ser entendida como um tema afeto à técnica, consequentemente surgiria uma tendência em no mínimo reduzir as competências do Legislativo. Apareceria nos debates jurídicos o tema da "nova" técnica legislativa, que deveria ser partilhada entre o Legislativo e o Executivo, ampliando as competências deste último. O tema da delegação legislativa vai ao encontro dessa objetividade técnica, alheia às "confusões" da política. Essa ampliação do poder normativo também reflete certa desconfiança pelo parlamento e suas potenciais (e perigosas) influências "populares". Ante as circunstâncias, até mesmo assumidos liberais seriam forçados a contribuir para uma

\footnotetext{
18 Sobre as relações entre direito e ideologia, vide WOLKMER, 2003.

${ }^{19}$ Mutatis mutandis, Habermas oferece uma interessante análise a respeito da técnica como ideologia e dominação das massas, notadamente após o surgimento do fenômeno intervencionista do Estado. Quando a técnica é incorporada à política, aquela acaba por absorver esta, esvaziando a esfera pública, centralizando as decisões em órgãos técnicos. (HABERMAS, 2006, p. 46; 71-72).
}

releitura da clássica teoria da separação de poderes, confiando ao Executivo o protagonismo normativo naquele momento crucial para a "modernização" do país.

\section{DELEGAÇÕES LEGISLATIVAS}

Venancio Filho, em obra capital, adotou a divisão sugerida por Bernard Chenot e analisou o tema da intervenção do Estado no domínio econômico a partir de dois aspectos: o direito regulamentar e o direito institucional. Esses aspectos seriam as facetas de um novo campo do direito, o direito público econômico. ${ }^{20}$ No primeiro, o Estado exerce um papel exclusivamente normativo; no segundo, desempenha uma atividade de agente econômico.

O modelo interventor de Estado favoreceu uma relação mais próxima entre direito e economia ("o econômico como conteúdo do direito"). Entre as consequências dessa aproximação surgiu a necessidade de um novo tipo de legislação, obrigando a um "reajustamento da ciência jurídica" e a um "deslocamento teórico". As regras próprias do direito econômico desafiariam os juristas a se desvencilharem da "estrutura clássica do direito", dos "sedutores, mas esterilizantes, esquemas da lógica formal". Tais normas possibilitariam aos poderes públicos agirem ativamente na economia (VENANCIO FILHO, 1968, p. 69). Logo, era preciso pensar em uma nova técnica legislativa.

O tema das delegações legislativas pode ser localizado nesse sub-ramo do direito regulamentar econômico, que, inevitavelmente, deságua em um dos capítulos mais clássicos e problemáticos da teoria política moderna: a tripartição dos poderes.

Para mostrar o debate em torno do tema, foram selecionados juristas influentes da época, tanto no meio político como no acadêmico, tais

${ }^{20}$ Sobre o tema na Alemanha, vide STOLLEIS, 2004. 
como Francisco Campos, Victor Nunes Leal, Bilac Pinto e Themistocles Cavalcanti. ${ }^{21} \mathrm{O}$ objetivo será demonstrar como um campo conceitual (delegação legislativa) possui autonomia em relação aos textos constitucionais. Muito embora presente já no contexto da Primeira República, a ideia de delegação se fortalece nos anos 30 e no pós-1946 permanece mesmo diante de expressa proibição constitucional. Inclusive, tal doutrina vai forçar a interpretação da Constituição de 1946 a ponto de surgir uma emenda abrindo possibilidades para a delegação. Os autores citados acima sustentarão esta doutrina pró-delegação nos diferentes momentos constitucionais, ora a partir e ora apesar da Constituição.

\subsection{Francisco Campos}

Aqui não é o espaço para uma longa biografia, mas é importante traçar brevemente a trajetória desse jurista brasileiro. Francisco Luiz da Silva Campos nasceu em 1891 na cidade de Dores do Indaía (MG) e morreu em Belo Horizonte em 1968. Graduou-se em Direito em 1914, foi professor de Direito e entrou na vida política em 1919, quando foi eleito deputado estadual em Minas Gerais. Durante o governo Vargas exerceu os cargos de Ministro da Educação, Consultor-Geral da República e Ministro da Justiça. Como Ministro da Justiça do primeiro governo Vargas, foi um dos responsáveis pela estruturação jurídica e política do Estado Novo, redigindo a Carta de 1937. Publicou inúmeras obras jurídicas e políticas e foi um dos mais influentes juristas de seu tempo. Sua obra mais representativa foi o "O Estado Nacional: sua estructura e seu conteúdo ideológico" (1940). Após sua "saída" do cenário

\footnotetext{
${ }^{21}$ Um interessante inventário sobre o tema pode ser encontrado em FONTES, [s.d.]. Ainda que o propósito deste artigo fora empreender uma análise histórica, o tema das delegações legislativas permanece nos debates jurídicos no Brasil. Vide BARROSO, [s.d.].
}

político ao final da década de 40 , volta ao centro da história nacional na coautoria do Ato Institucional n. ${ }^{\circ} 1$, em $1964 .{ }^{22}$

Ao lado de autores como Oliveira Vianna, Julio de Castilhos e Alberto Torres, Campos é assimilado como um dos grandes nomes do pensamento antiliberal (autoritário). ${ }^{23}$ Alinhado em sua crítica ao modelo liberal, sua proposta de Estado também era antiliberal, pelo menos no período em que o autor adaptou-se ao figurino autoritário.

Ele propunha, entre outros pontos, uma releitura da liberal teoria da separação de poderes, já que "Cada época tem a sua divisão de poderes, e a lei do poder é, em política, a da capacidade para exercê-lo." (CAMPOS, 1945, p. 346). A teoria da separação dos poderes era uma mecânica histórica que não obedecia a uma lei natural eterna e atemporal. Assim sendo, o

${ }^{22}$ Melhores informações sobre a biografia do autor, vide MEDEIROS, 1978.

${ }^{23}$ Entretanto o Francisco Campos ministro do Estado Novo era diferente daquele Francisco Campos advogado de empresas concessionárias, sobretudo em seus pareceres com contornos liberais. "Tanto naquele período quanto no que se seguiu à Revolução de 30, os escritos de Campos como homem público e jurisconsulto tendiam a defender o nacionalismo, o antiformalismo, a supremacia do interesse público e do direito que o regia. Posteriomente, em pareceres favoráveis a empresas, haveria uma relativização de tais inclinações. [...] O parecerista dos anos 50 e 60 nem sempre revelava, tampouco, o teórico e legislador nacionalista dos anos 30. Em benefício de seus clientes, Campos soube contornar criativamente nosmas destinadas a diminuir a influência estrangeira no mercado de seguros. E não hesitou em defender - contra o texto da Constituição vigente - a atuação estrangeira em empresas do setor periodistico. [...] $\mathrm{Na}$ defesa de sua clientela, o jurista mineiro não falhava, nem mesmo quando pretendia demonstrar que altas multas impostas ao público decorriam do interesse público. [...] As fontes aqui analisadas, em suma, não parecem reforçar a visão usual de Campos como expressão de um autoritarismo monolítico e de um autoritarismo sistemático. Pelo contrário, revelam um jurista extremamente adaptável às circunstâncias políticas e econômicas - sem compromissos definitivos nem com ortodoxias doutrinárias, nem com movimentos políticos, nem com os interesses de sua classe de origem. Um jurisconsulto adaptável - como tantos outros em nossa história." (SEELANDER; CASTRO, 2010, p. 317; 318; 319) 
jurista pensava numa reforma constitucional que adequasse as instituições à nova democracia antiliberal de massas. Como a democracia de massas era a ditadura de um líder, o clássico modelo liberal de separação de poderes, centralizado na figura do parlamento, deveria ser revisto. Tal revisão caminhava no sentido de abandonar o legislativo como centro de gravidade da decisão política e transferir esse centro ao Executivo. O parlamento, além de representar a arena dos interesses locais partidários e egoísticos, não estava tecnicamente preparado para decidir sobre os complexos e urgentes problemas sociais, econômicos e políticos da época. ${ }^{24}$

$O$ poder de expedir decretos-leis se justificava por imperativos de responsabilidade e eficiência. Na medida em que a Carta de 1937 tinha ratificado o Presidente da República como o chefe administrativo do Estado, a ele caberia a responsabilidade pela ação administrativa. O dever de responsabilidade pela ação administrativa seria acompanhado do poder para remodelá-la a partir das circunstâncias. Quanto à eficiência, o parlamento era concebido como uma instância política inapta para as questões sociais complexas e urgentes da época e como a "lei da política" é a impossibilidade de "vazios de poder" ("poder vago, poder ocupado"), o Executivo seria o legítimo ocupante desse "vazio". Legítimo porque eficiente, responsável e comandado pelo chefe democraticamente aclamado. (CAMPOS, 1946, p. 346-347) $)^{25}$

\footnotetext{
${ }^{24}$ Carl Schmitt, discorrendo sobre Donoso Cortés, também trata da inépcia dos parlamentos e da burguesia liberal. "Una clase que traslada toda actividad política al plano de la discusión, en la Prensa y en el Parlamento, no es capaz de hacer frente a una época de luchas sociales." (2006, p. 52) (Uma classe que transfere toda a atividade política ao plano da discussão, na Imprensa e no Parlamento, não é capaz de fazer frente a uma época de lutas sociais.) (Tradução livre).

${ }^{25}$ Referendando essa centralidade do Executivo, a Carta de 1937, no auto de outorga, já entrava em suspensão tendo em vista a decretação do estado de emergência, bem como foi dissolvido o poder legislativo em âmbito nacional.
}

Além do poder constitucional de expedir decretos-leis, Campos fazia uma diferenciação entre política legislativa e técnica legislativa. ${ }^{26}$ A política legislativa estava a cargo do Legislativo, que deveria cuidar politicamente dos fatos mais relevantes e estabelecer leis de conteúdo principiológico. Já a técnica legislativa, a cargo do Executivo e seus órgãos, se materializava em decretos-leis e regulamentos para a vida cotidiana. A técnica legislativa não era dependente da política legislativa, daí a existência de decretos autônomos. (CAMPOS, 1946, p. 341).

Tendo em vista a complexidade técnica dos assuntos de governo, o parlamento se reduziria à função de estabelecer apenas a substância e os princípios gerais que deveria direcionar um tema. Dentro dessa órbita principiológica, caberia ao Executivo, por meio do poder regulamentar, dar forma prática aos princípios legais. O regulamento executivo era o instrumento técnico adequado para dar conta da complexidade da vida moderna. (CAMPOS, 1946, p. 342)

Para o jurista, a partir do momento que o Estado encampou funções positivas de governo, a legislação perdeu seu caráter exclusivamente político, com isso os parlamentos perderam seu monopólio legislativo. ${ }^{27}$ Dessa forma, o que não faltavam eram razões a justificarem as delegações legislativas. Segundo o autor, a delegação do poder legislativo era um sinal de modernidade, tanto que era o regime adotado na Inglaterra e nos Estados Unidos. Mais uma vez Campos, não haveria, no mundo, qualquer obra legislativa importante que não tivesse sido iniciada pelo Executivo ou delegada pelo Legislativo. (CAMPOS, 1946, p. 341-342).

\footnotetext{
${ }^{26}$ Essa distinção foi importada e adaptada da obra do inglês Harold Laski. Vide LASKI, 1950; MENEZES, 1943 27 “[...] está no domínio público, [...] que não passa de mera ficção ou de anacronismo ideológico a tese de que a função legislativa cabe exclusivamente ao parlamento." (CAMPOS, 1946, p. 344)
} 
O Estado Moderno interventor, a fim de se harmonizar ao Estado de Direito, deveria ser exercido pela lei. Mas, ante as complexidades sociais e econômicas, a lei tinha se tornado uma "imensa técnica" em que "só a ação dá conhecimento direto da matéria". Ou seja, a parcela do Estado destinada a exercer a intervenção ( "em contacto com a realidade") era aquela mais apta tecnicamente para "completar" as regras, dentro de um quadro definido pela lei parlamentar ("política legislativa"). Mas note-se que esse ato complementar destinado à "técnica legislativa" (Executivo) era essencialmente "elástico" a ponto de promover correções e extensões aos dispositivos legais. Por isso que, para Campos, o clássico poder regulamentar, de natureza meramente executória, era insuficiente.

\subsection{Victor Nunes Leal}

Mineiro, nascido em 11.11.1914, foi um jurista de destaque em sua época, ocupando diversos cargos públicos. Cursou direito na Faculdade Nacional de Direito (RJ) diplomandose em 1936. Foi um dos fundadores da Revista de Direito Administrativo. ${ }^{28}$

Trabalhou no gabinete do Ministro Gustavo Capanema durante o Estado Novo. Lecionou Ciência Política na Faculdade Nacional de Filosofia e lecionou no DASP, na Escola de Estado-Maior do Exército e proferiu conferências na Escola Superior de Guerra. Compôs o corpo de professores da Universidade de Brasília, desde a sua fundação.

Inicialmente militou na advocacia até ser nomeado Procurador-Geral de Justiça no antigo Distrito Federal, lá permanecendo de março a novembro de 1956, quando foi investido na Chefia da Casa Civil da Presidência da

28 Referências biográficas extraídas do site <http://www.stf.jus.br/portal/ministro/verMinistro.asp?peri odo=stf\&id=108>. Acesso em 03.11.2015.
República, cargo que exerceu até agosto de 1959.

Exerceu os cargos de Advogado da antiga Prefeitura do Distrito Federal, de ConsultorGeral da República (fevereiro a outubro de 1960) e de Procurador do Tribunal de Contas do Distrito Federal (outubro a dezembro de 1960). Em novembro de 1960, foi nomeado Ministro do Supremo Tribunal Federal pelo então Presidente da República Juscelino Kubitschek de Oliveira.

Foi aposentado compulsoriamente da Corte em 16 de janeiro de 1969, nos termos do Ato Institucional $\mathrm{n}^{\circ} 5$, de 13 de dezembro de 1968, não tendo sido preenchida a vaga em face do Ato Institucional $\mathrm{n}^{\circ} 6$, de $1^{\circ}$ de fevereiro de 1969, que reduziu de 16 para 11 o número de Ministros do Supremo Tribunal Federal, restabelecendo a composição anterior ao Ato Institucional $\mathrm{n}^{\mathrm{o}} 2$, de 27 de outubro de $1965 .^{29}$ Após a aposentadoria, retornou à advocacia.

Publicou vários artigos, a maioria deles na Revista Forense e Revista de Direito Administrativo, muitos deles reunidos na obra Problemas de Direito Público e outros problemas (1960). Também se destacam os pareceres do autor durante o exercício do cargo de Consultor-Geral da República (1966).

Publicou vários artigos, a maioria deles na Revista Forense e na Revista de Direito Administrativo, muitos deles reunidos na obra Problemas de Direito Público e outros problemas (1960). Também se destacam os pareceres do autor durante o exercício do cargo de Consultor-Geral da República (1966). Sua obra de maior destaque foi Coronelismo, Enxada e Voto (1948), com ampla repercussão no âmbito das ciências sociais. Faleceu em 17 de maio de 1985, no Rio de Janeiro.

Para o autor, modernamente a lei era a principal fonte do direito já que, citando Kirchmann, "Bastam três palavras do legislador

29 Sobre a atuação de Nunes Leal no STF durante a ditadura de 1964, vide CURI, 2010, p. 448-495. 
para inutilizar bibliotecas inteiras!" (1997b, p. 08). Assim sendo, a elaboração da lei exigia "precauções severíssimas", "como se estivesse acondicionando materiais explosivos." (NUNES LEAL, 1997b, p. 08)

Modernamente, em razão da ampliação dos poderes do Estado, a quantidade de leis tinha aumentado consideravelmente e existia uma ordem hierárquica a se obedecer: constituição, lei e regulamento. Os regulamentos deviam se conter dentro das leis e estas dentro da constituição. As normas de grau inferior desenvolviam os princípios das de grau superior, eis que "Maior graduação corresponde a maior generalidade. [...] A Constituição deve enfeixar normas mais concisas, mais gerais e em menor número; [...]." (NUNES LEAL, 1997b, p. 1011)

Para evitar as intermináveis discussões entre lei e regulamento, o melhor seria que se previssem na Constituição as delegações legislativas a fim de "facilitar, por via executiva, a reforma de algumas disposições das leis, que contem estas as necessárias delegações legislativas." (NUNES LEAL, 1997b, p. 12)

Afirmou que não foram as delegações legislativas que criaram o Estado Novo, mas o Estado Novo que, entre outros expedientes, fez uso das delegações para reforçar o seu poder autoritário. As delegações legislativas não eram um fenômeno exclusivo de estados autoritários, já que também apareciam em estados de índole democrática, como nos Estados Unidos e na Inglaterra (reportando-se a texto do "professor" Francisco Campos).

Por isso Nunes Leal argumentou que não se sustentava a proibição das delegações legislativas pura e simplesmente pelo medo de fortalecimento do Executivo. Tais expedientes, ou seja, as delegações legislativas - desde que houvesse um Parlamento funcionando adequadamente, o que se esperava depois da Constituição de 1946 -, seriam um interessante instrumento de governo. A proibição das delegações legislativas favoreceria as forças conservadoras, impedindo "medidas legislativas rápidas", sobretudo no campo econômico, que iriam contra os interesses daquelas forças (Nunes Leal, 1997c, p. 98). Nota-se que, para o jurista, as delegações legislativas poderiam funcionar como uma das ferramentas jurídicas para a modernização do Estado.

A difícil relação entre lei e regulamento se intensificava nos regimes que proibiam as delegações; nos que permitiam, as dificuldades tendiam a se atenuar. Naqueles regimes, além de se verificar a adequação do regulamento com a lei, era preciso, primeiro, analisar se os termos da lei não redundavam em uma delegação legislativa proibida. Como o regulamento carregava em si certa medida de autoridade delegada, para Nunes Leal haveria uma dose de contradição entre proibir as delegações legislativas e conservar a faculdade administrativa regulamentar. Nesse sentido, o regime pós Constituição de 1946 deixaria à doutrina e ao Judiciário sérios problemas a enfrentar. (NUNES LEAL, 1997c, p. 103)

Demonstrando as raízes históricas do problema, Nunes Leal afirmava que o STF, durante a Primeira República, em vários casos contornou o problema das delegações legislativas ampliando o conceito de poder regulamentar. Ou seja, a Corte admitia a proibição das delegações legislativas, no entanto, reconhecia um "exercício normal de uma autoridade própria", conferido diretamente pela Constituição ao Executivo. O jurista cita acórdãos de 1915, 1921 e 1923, destacando que: Segundo a doutrina modernamente ensinada por
publicistas de incontestado valor, o poder de
regulamentar do Presidente da República é amplo,
pode inovar na matéria legislada, sanando qualquer
lacuna do ato legislativo. [...] Êste os expede por si
mesmo, exercendo funções constitucionalmente
suas, com a mesma firmeza autoridade e
independência com que o Legislativo decreta as
suas leis e o judiciário profere a suas decisões. 
Ante a esses precedentes, Nunes Leal previa que o Judiciário, mesmo frente à proibição das delegações legislativas (Constituição de 1946) viesse a resgatar aquele "antigo e amplo" conceito de poder regulamentar. $\mathrm{O}$ autor acrescentava que a tese da inconstitucionalidade manifesta também poderia funcionar como mais um argumento para o Judiciário contornar a proibição constitucional. (NUNES LEAL, 1997c, p. 104). ${ }^{30}$

Fica claro que para o jurista as delegações legislativas não eram, em si, mecanismos autoritários, elas poderiam conviver com o regular funcionamento dos parlamentos e sua proibição não era a melhor alternativa. Sobretudo, a advertência deixada pelo autor é emblemática, mesmo após a proibição constitucional (Constituição de 1946) não era possível simplesmente apagar uma prática de delegações legislativas, e havia argumentos (jurisprudência inclusive) para, de alguma forma, interpretar a nova Constituição contornando tal proibição, a partir de uma tradição hermenêutica.

Não por acaso, a Inglaterra reviu seu sistema. Optando por um modelo de maior flexibilidade entre os poderes, substituiu o "sistema de poderes rivais por outro, de conjugação de poder, através do regime parlamentarista." (NUNES LEAL, 1955, p. 109). Já os Estados Unidos encontravam-se, ainda, enfrentando as dificuldades de uma organização política que se opunha "ao bom andamento dos negócios públicos." (1955, p. 110). Muito embora essas dificuldades, os norteamericanos estavam adotando soluções "um pouco à margem do aparelho constitucional."

Nunes Leal conclui que a tradicional teoria da separação de poderes era uma construção doutrinária superada pelos fatos. Não mais

30 Princípio de que a inconstitucionalidade somente poderia ser pronunciada pelo Judiciário quando fosse manifesta.

correspondia às "necessidades modernas". O Estado ativo era uma fatalidade, independentemente da ideologia que se instalasse no poder.

\subsection{Olavo Bilac Pinto}

As delegações legislativas não foram tratadas apenas em artigos e manuais jurídicos, ganharam espaço, também, nos pareceres, o que sinaliza a repercussão prática do tema. Neste item veremos um parecer do jurista Olavo Bilac Pinto. A fonte de referência do autor será um parecer emitido em julho de 1946, tratando dos poderes do Instituto do Açúcar e do Álcool (I.A.A.). ${ }^{31}$ Em síntese o parecer examinou pontos da decisão administrativa da Comissão Executiva do I.A.A. que caracterizou como fornecedores de cana-de-açúcar alguns colonos na região de Piracicaba/SP, mesmo depois da Justiça paulista já ter decidido de forma contrária. O momento histórico era o da Carta de 1937. (BILAC PINTO, 1953, p. 250)

O jurista nasceu em Santa Rita do Sapucaí, em Minas Gerais, em 8 de fevereiro de 1908, filho de João Pereira Pinto e de Laura Pereira Pinto. Cursou a Faculdade de Direito de Minas Gerais, diplomando-se em 1930. Foi advogado criminal em Belo Horizonte e professor de Noções de Direito no Departamento de Instrução da Força Pública de Minas Gerais. Em 1934 elegeu-se Deputado à Assembleia Constituinte $\mathrm{e}$ à Assembleia Legislativa de Minas Gerais, no ano de 1935, tendo sido cassado após o golpe de Estado de 1937. Dirigiu a Revista Forense. Em 1940 foi membro da Comissão Especial, nomeada por Francisco Campos para elaborar o anteprojeto da Lei Federal de Regulamentação dos Serviços de Utilidade Pública. Em 1943 tornou-se professor catedrático de Direito Administrativo na Faculdade Nacional de Direito da Universidade do Brasil (RJ), mas foi

${ }^{31}$ BILAC PINTO, 1953. 
aposentado compulsoriamente, nos termos do artigo 177 da Carta de 1937, por ter subscrito o "Manifesto dos Mineiros", vindo a ser reintegrado em 1946. Nos anos de 1944 a 1945 viajou aos Estados Unidos para estudos. Foi líder da bancada da UDN na Câmara dos Deputados no ano de 1962. Em 1963 foi eleito presidente do diretório nacional da UDN. Em 1965 tornou-se presidente da Câmara dos Deputados. De 1966 a 1970 foi Embaixador do Brasil na França. Em 1970 foi nomeado ministro do Supremo Tribunal Federal, por Emílio Garrastazu Médici, na vaga decorrente da aposentadoria de Themistocles Brandão Cavalcanti. Aposentado da Corte em 1978, por implemento da idade. Faleceu em 18 de abril de 1985, no Rio de Janeiro.

Para Bilac Pinto a questão de fundo redundava na inevitável discussão sobre a separação de poderes, para ele um "principio essencialmente político" que, ao ser incorporado ao direito público, adquiria "valorização $e$ conteúdo jurídicos." (1953, p. 236). ${ }^{32} \mathrm{O}$ jurista procurou demonstrar, na introdução de seu parecer, que, ao se examinar a história constitucional do Brasil, não era possível encontrar uma tendência unívoca sobre $\mathrm{o}$ princípio da separação de poderes. Portanto, como não havia no país uma tradição especifica, o princípio estava à mercê das circunstâncias históricas.

A crítica da época, segundo Bilac Pinto, era que o princípio da separação de poderes estava historicamente superado e era insuficientemente flexível para se adaptar à "rápida transformação operada no Estado." 33

\footnotetext{
${ }^{32}$ Citando um julgado americano (People v. Tremaine, 252, NY. 27, 168 N.E. 817-1929): “[...] como todos os caminhos levam a Roma, tôdas as questões do direito público conduzem, cedo ou tarde, à separação dos poderes". (BILAC PINTO, 1953, p. 236)

33 "A estrutura orgânica e funcional do Estado, modelada no pressuposto do quadro econômico e social do laissezfaire, teria, necessariamente, que se manifestar inadequada para atender aos novos tipos de atuação que dele se reclamava.” (BILAC PINTO, 1953, p. 251)
}

Assim sendo, "os desvios mais reiterados, insistentes e inevitáveis do principio passaram a ser a delegação legislativa e a outorga de funções jurisdicionais a agências administrativas." (BILAC PINTO, 1953, p. 248). ${ }^{34}$

Tais estratégias de "fuga" da separação de poderes, muito embora configurassem flagrantes violações ao princípio, já que fundadas em uma "confusão" de poderes, teriam se tornado comuns em "todos os países". (BILAC PINTO, 1953, p. 249). Sobre os Estados Unidos, a partir de Frederick F. Blachly e M. Oatman (Administrative Legislation and Adjudication), Bilac Pinto concluiu que naquele país ${ }^{35}$ :

Os mais ortodoxos doutrinadores foram levados a admitir a existência de funções que denominam de 'quase-legislativas' ou de 'quase-jurisdicionaes, desempenhadas como parte da atividade administrativa. [...] A legislação e a jurisdição administrativas tornaram-se características significativas da função governamental. (1957, p. 255)

Bilac Pinto destaca a maneira com que as delegações legislativas vinham se consolidando nos Estados Unidos, além e apesar dos textos e tradições constitucionais. ${ }^{36}$ No entanto, não obstante uma cultura constitucional contrária às delegações legislativas, ganhava força uma "prática constitucional" que tacitamente as acolhia, ante as necessidades econômicas e sociais. A própria Suprema Corte, talvez por apego formal às tradições constitucionais, admitia a autoridade das delegações, mas lhe negava o caráter "legislativo", recusando-se a

\footnotetext{
34 Uma síntese sobre o Direito Administrativo norteamericano, vide GIACOMINI, 2016, p. 371-379.

${ }^{35} \mathrm{O}$ debate sobre o tema se inicia com o Administrative Procedure Act de 1946, que outorgou à agências poderes de natureza legislativa e judicial.

36 “O que mais impressiona nessa irreprimível tendência é que ela caminha constantemente, a despeito do ortodoxismo teórico, dos textos categóricos das Constituições, dos julgados antagônicos." (BILAC PINTO, 1953, p. 273)
} 
“dizer que uma pá é uma pá." (BILAC PINTO, 1953, p. 274)

Por isso que grande parte da doutrina e da jurisprudência se sentia mais à vontade, e quem sabe menos culpada, em conceber a delegação como uma outorga de poderes "quase legislativos". Aceitava-se materialmente a delegação, recusando-se, porém, em emprestar o termo "legislativo". Era uma questão menos de substância do que de terminologia. ${ }^{37}$

Por outro lado, Bilac Pinto procura demonstrar que aquela realidade norte-americana atravessara o Atlântico e era possível encontrar no Brasil órgãos, autarquias, fundações e até sociedades de economia mista exercendo atribuições normativas delegadas. A fim de enfrentar a nova realidade vivenciada no país, não obstante $\mathrm{o}$ custo constitucional a ser enfrentado, o parecerista concluiu pela necessidade de revisão da separação de poderes, concebendo-se formas de delegação legislativa e a outorga de funções jurisdicionais a órgãos e entidades administrativas.

\subsection{Themistocles Brandão Cavalcanti}

Themistocles Brandão Cavalcanti nasceu no Rio de Janeiro e ingressou na Faculdade de Ciências Jurídicas e Sociais do Rio de Janeiro no ano de 1918, vindo a se formar em 27.12.1922. De 1922 a 1930 advogou na defesa de militares envolvidos no movimento tenentista, compartilhando o escritório com Nilo Peçanha. Em 1924, durante o estado de sítio no governo Arthur Bernardes, chegou a ser preso por sua atuação na defesa de alunos da Escola Militar do Realengo/RJ, que foram expulsos e sujeitos a pena disciplinar ou mesmo processo criminal

\footnotetext{
37 "'Pouca gente se apercebe da grande intensidade com que a Administração pública no Govêrno nacional norteamericano é controlada por meio de regulamentos ou decretos administrativos com a autoridade formal de legislação." (JOHN A. FAIRLIE apud BILAC PINTO,
} 1953, p. 276) ante a revolta de 05.07.1922. Advogou também para oficiais que participaram dos eventos de 1922 (Forte de Copacabana). Além dos cadetes e tenentes de 1922, Cavalcanti defendeu os revolucionários paulistas de 1924, estreitando os laços com o Conselheiro Antônio Prado. Participou da fundação do Partido Democrático (PD) de São Paulo (1926).

Teve uma longa e importante carreira como doutrinador do direito administrativo e constitucional, bem como ocupou importantes cargos públicos. Sua carreira jurídica se destaca no pós-1930, quando aderiu à Aliança Liberal alistando-se nas forças armadas de Minas Gerais. Apoiou os setores tenentistas, tendo sido, inclusive, o primeiro secretário e um dos cofundadores do Clube 3 de Outubro.

Cavalcanti ocupou os seguintes cargos e integrou as seguintes comissões: Procurador do Tribunal Especial (1930); ${ }^{38}$ Procurador da Junta

${ }^{38}$ Tribunal criado pelo governo provisório por meio do Decreto 19.440/1930 para julgar antigos agentes (políticos ou não) da república velha. Cavalcanti, baseado no relatório final das sindicâncias, declarou à imprensa do Rio de Janeiro que não havia provas para afirmar a desonestidade do ex-presidente Washington Luis. O Tribunal Especial foi extinto em março de 1931 e Cavalcanti elaborou um projeto para transformá-lo em Junta de Sanções, que foi instalada em abril do mesmo ano, composta por três juízes ministros de Estado: Oswaldo Aranha (Justiça), Gal. José Leite de Castro (Guerra) e Francisco Campos (Educação e Saúde). Ainda em 1931 elaborou outro projeto de transformação da Junta em Comissão de Correição Administrativa, que foi criada em setembro de 1931. Essa comissão abandonou os processos políticos e concentrou-se na área administrativa. A justiça revolucionária, por meio da sucessão desses três órgãos, instaurou mais de trezentos processos. <http://www.fgv.br/cpdoc/busca/Busca/BuscaConsultar.as px>, acesso em 02.09.2014. Sobre sua atuação nesses tribunais, Cavalcanti teceu considerações em artigo publicado em 1978, destaco alguns excertos: “[...] os próprios objetivos da justiça revolucionária eram imprecisos, porque ela não excluía os objetivos políticos e cogitava essencialmente da punição dos que possivelmente se teriam locupletado com os dinheiros públicos. A imprecisão dessa finalidade e a formulação post factum desses delitos dificultavam muito a aplicação a fatos anteriores não qualificados como criminosos. Não me arrependi de ter participado de três tribunais como procurador. Nem sequer a minha pouca idade 
de Sanções (1931); Procurador da Comissão de Correição Administrativa (1931); Procurador da República (1931-1932); Membro da Comissão Consultiva do DF (1932); ${ }^{39}$ Membro da Comissão Elaboradora do Anteprojeto da Constituição de 1934, do Itamarati (1933); Procurador da República no DF (1938-1945); Consultor-Geral da República (1945-1946; 1955); Procurador-Geral Eleitoral (ad hoc por diversas vezes e efetivo em 1946) e ProcuradorGeral da República (1946-1947); Presidente da

inexperiência justificariam o meu arrependimento que, como já disse, não existiu. $\mathrm{O}$ efeito da criação desses tribunais foi, antes de tudo, moral, e constituiu uma importante documentação sobre fatos anteriores a 1930. Para a história, fiz esse pequeno relato do que foi a justiça revolucionária. A ela não se pode fazer as mesmas acusações que sucederam ao tribunal de Nurembergue (sic), embora ainda reconheça a legitimidade daquele tribunal, cujos excessos passarão, também, à história. [...] A organização da justiça revolucionária e a escolha de seus membros obedeceram a inspiração idêntica àquela que motivou a própria composição do Governo, quer dizer, a organização de um tribunal constituído de pessoas qualificadas entre os próceres da Revolução e que tivessem o seu espírito. [...] constituído por homens imbuídos da vontade de ver imposto ao País um regime de liberdade, fundada na prática da democracia, e do propósito bem marcante de ver reformados os costumes políticos e as práticas administrativas então vigentes. [...] um tribunal constituído por homens da classe média, homens de boa tradição jurídica e política. [...] eu mesmo, ainda moço, já com uma tradição liberal, advogado que sempre fui de causas liberais. [...] Não foi brilhante a atuação da Junta de Sanções [...] Esta amadurecia no sentido de uma evolução de seu conceito: de repressivo, de aplicador de sanções para um outro, de revisão administrativa, [...] Eu, pessoalmente, nunca dei importância às críticas ou louvores feitos ao tribunal revolucionário. [...] fazia parte de um tribunal revolucionário e procurava exercer as minhas funções dentro de critérios que havia estabelecido. Não tinha interesse político nenhum. $\mathrm{O}$ meu interesse era fazer justiça e cumprir uma tarefa, que para mim, como moço que era, se destinava a servir de orientação a minha vida futura. [...] O que se exigia era uma modernização e uma reformulação nova de conceitos políticos, administrativos e econômicos. [...] Não me arrependi de nela ter trabalhado. Tarefa honesta de jovem idealista e que não me trouxe lucro, mas muito sacrifício, muita calúnia, muita injustiça. Mas era de se esperar." (CAVALVANTI, 1978b, p. 4; 5; 6; 7).

${ }^{39}$ Nomeado por Pedro Ernesto, prefeito do Rio de Janeiro e amigo pessoal de Cavalcanti. O objetivo da comissão era dar pareceres sobre os projetos de decretos-leis elaborados pelo prefeito.
Comissão de Tarifas do Serviço Público e da Comissão Revisora do Código Rural (1945). ${ }^{40}$

Em 1960 foi eleito deputado à Assembleia Constituinte da Guanabara pela legenda da União Democrática Nacional (UDN). Após a promulgação da Constituição, exerceu o mandato ordinário até 1961, quando renunciou. ${ }^{41} \mathrm{Em}$ 1966 fez parte da comissão especial de juristas, nomeada pelo marechal Castelo Branco visando à elaboração de um novo projeto constitucional. Foi ministro do STF durante a ditadura militar, sendo indicado para o cargo pelo então General de Exército Arthur da Costa e Silva, ante a aposentadoria do Ministro Hahnemann Guimarães, cargo que exerceu de 18.10.1967 a 14.10.1969 (aposentadoria compulsória por idade), mantendo-se na Corte mesmo após o expurgo de $1968 .{ }^{42} \mathrm{Na}$ qualidade de Ministro do

40 Disponível

em:

<http://www.stf.jus.br/portal/ministro/verMinistro.asp?peri odo=stf\&id=105>. Acesso em 23 ago. 2014.

${ }^{41}$ Em 1960, quando houve a mudança da Capital Federal, o atual Distrito Federal passou a integrar a federação como Estado da Guanabara. Para tanto, foi convocada uma assembleia constituinte (poder constituinte derivadodecorrente), a fim de se confeccionar a constituição do novo estado-membro. Vide Lei 3.752/1960.

42 Durante sua atuação no STF, vale destacar o HC 45.232/Guanabara de fevereiro de 1968, sob a relatoria de Cavalcanti, em que o tribunal efetuou uma operação de controle de constitucionalidade digna de nota entre as realizadas no período de ditadura militar pós-64. Por meio desse HC questionou-se a constitucionalidade do artigo 48 da Lei de Segurança Nacional (Decreto-lei $n^{\circ} 314$, de 1967). Cavalcanti se baseou na jurisprudência da Suprema Corte norte-americana para declarar a inconstitucionalidade do dispositivo legal. Sua argumentação funda-se em dois posicionamentos básicos. O primeiro, que era possível declarar a inconstitucionalidade de uma norma mesmo quando ela não violasse dispositivo literal da Constituição ("Não é preciso que esteja expressa a garantia, basta que ela decorra do sistema político e do conjunto dos princípios expressos."). O segundo, que o direito à vida não era apenas o de não ser morto, mas também o de ter condições de manter a própria sobrevivência. Essa decisão é importante, pois é uma das poucas em que o STF se contrapôs claramente a um ato da ditadura militar com base na lei de segurança nacional. Vale registrar que na época não havia o AI-5, depois dele as coisas mudaram de figura. Sobre as transformações do STF e do controle de 
STF integrou a "comissão constitucional de alto nível" nomeada por Costa e Silva em 1968 com o intuito de elaborar emendas à recente Carta de 1967, reforçando o poder central e o Executivo, bem como legitimando medidas autoritárias do regime.

Dirigiu a Faculdade Nacional de Ciências Econômicas da Universidade do Brasil (RJ) no período de 1945-1960, onde foi o titular da disciplina de Instituições de Direito Público. Foi membro do Conselho Universitário e de suas Comissões de Legislação e Orçamento (19461960) e do Conselho do Instituto de Ciências Sociais da Universidade do Brasil, ocupando a Presidência, em $1964 .{ }^{43}$ Foi diretor do Instituto de Direito Público e Ciência Política da FGV. Também lecionou na PUC/RJ e foi agraciado com o título de professor honoris causa pelas Universidades de Toulouse e Poitiers, bem como pela e ESG (Escola Superior de Guerra), onde proferiu diversas palestras, nomeadamente nos anos 50 e 60, inclusive às vésperas do golpe de 64 e posteriormente. ${ }^{44}$

$\mathrm{O}$ autor construiu uma promissora carreira, assumindo cargos públicos importantes, bem como elaborou uma vasta doutrina em direito administrativo e em temas de direito constitucional e ciência política, sendo lembrado nos manuais da matéria como um dos principais nomes do direito administrativo pátrio

constitucionalidade durante a ditadura militar, vide KOERNER, 2013.

${ }^{43}$ Este é um dado relevante já que sugere que o autor exerceu influência na formação de quadros profissionais voltados à administração pública, levando em consideração a significativa presença de juristas como gestores da economia nacional (Celso Furtado, Roberto Campos, etc.). Entretanto, é possível constatar o fenômeno inverso, ante a atuação de economistas e administradores na formação do direito público, v.g. na elaboração do Decreto-lei 200/67. (SALINAS, 2010, p. 529-530).

44 Themistocles Cavalcanti iniciou suas conferências na ESG no ano de 1952. Não foi possível encontrar a data em que o autor recebeu o título de professor honoris causa na instituição, mas ocorreu no início de década de 60. Sobre a ESG, sua ideologia e sua influência no pensamento político nacional vide FERREIRA, 1979.
(BANDEIRA DE MELLO, 2007, p. 145). O jurista faleceu no Rio de Janeiro, em 19 de março de 1980. ${ }^{45}$

O fenômeno interventivo, para Cavalcanti, era uma tendência moderna. Sobretudo após as grandes guerras, o mundo atravessava sensíveis transformações na política, na economia e na cultura. O ser humano já não era mais o mesmo e o mundo estava dominado pela técnica. (CAVALCANTI, 1958, p. 07).

O índice de valores e o seu padrão sofreram modificações - os homens representativos são outros - outra a concepção do heroísmo, das virtudes essenciais - D. Quixote foi substituído por Flash Gordon. A vida espiritual também foi obrigada a se transformar. O romantismo tranqüilo, seguro, com a sensibilidade e a emoção de suas expressões sociais, literárias, artísticas, foi substituído pela vida perigosa, pela luta, pela mobilidade. (CAVALCANTI, 1958, p. 07).

Em meio a esse mundo técnico e em constante revolução, as instituições políticas e administrativas deveriam passar por uma reforma. A grande "crise do Estado moderno" estava justamente no choque entre as velhas ideias e os novos desafios. Deveriam ser repensados os modelos liberais sobre os quais foram construídas a maioria das instituições políticas.

Segundo Cavalcanti, "o direito administrativo é uma consequência da ampliação da intervenção do Estado em setores até há pouco imunes à sua influência" (1943, p. 469), isso se sentia, sobretudo, nos capítulos referentes ao poder normativo da administração, aos serviços públicos, às autarquias e institutos públicos e às empresas estatais.

Para o autor o problema dos parlamentos tinha ficado no século XIX, o século XX era a vez do Executivo. O jurista sempre se mostrou simpático às delegações legislativas, desde

${ }^{45}$ Mais informações sobre a trajetória do autor, bem como sua influência no direito público brasileiro no período do pós-1930, vide MESURINI, 2016. 
quando participou da Comissão do Itamaraty (1933). Digna de reflexão é a visão do autor sobre a Constituição de 1946. A Revista de Direito Administrativo, publicação de janeiro a março de 1947, é inaugurada com um breve, porém sugestivo texto de Cavalcanti, no qual se percebe que a nova constituição não agradou totalmente o jurista.

Os constituintes de 1946, graças ao "resultado de uma experiência das práticas administrativas e políticas", puderam tratar objetivamente de determinados temas essenciais. Se acertaram nos fins, erraram, porém, nos meios. O êxito da nova constituição estava a depender de sua "boa aplicação $e \quad d a$ interpretação dos seus preceitos". (CAVALCANTI, 1947, p. 01). A Constituição de 1946 adotara "critérios excessivamente ríspidos", nomeadamente ante a sua "ausência de elasticidade no mecanismo dos poderes e do próprio regime." (CAVALCANTI, 1947, p. 02). Tinha acolhido um "isolamento dos poderes" $\mathrm{e}$ um "apego excessivo à propriedade individual", dificultando sua adaptação às circunstâncias políticas e econômicas, que exigiam "maior flexibilidade" para uma "harmonia mais perfeita na colaboração entre os poderes do Estado." (CAVALCANTI, 1947, p. 02)

Portanto, o destino da Constituição de 1946 estava em sua hermenêutica, dependeria de uma "boa interpretação", fundada na doutrina pró-delegação. O tom crítico do autor quanto ao mecanismo dos poderes presente da Constituição de 1946 permaneceu em praticamente todos os seus escritos durante o período de vigência da constituição. Um dos textos mais representativos do período, relacionando intervenção estatal e deslocamento das funções legislativas é $O$ Estado e a ordem econômica - Problemas de técnica legislativa. ${ }^{46}$ Para Cavalcanti, o tema daquela conferência estava dentre aqueles "problemas insolúveis do direito e da economia de nossos dias".

Cavalcanti salienta a insuficiência da concentração do poder normativo no legislativo e a sua necessária "diluição", já que o poder regulamentar do Executivo não bastava.

Ainda mais, a concentração do poder normativo no Congresso, o monopólio da atividade legislativa sem reservas, constituirá sempre obstáculo a execução dessas leis, o que sòmente poderá ser obtido pela diluição do poder normativo através de um conjunto de normas complementares só possíveis em um regime mais flexível. O simples poder regulamentar do Executivo não basta - é uma atividade subordinada e restrita. É preciso descentralizar o poder normativo e atribuir certa autonomia aos órgãos técnicos de execução. (CAVALCANTI, 1951, p. 446).

Importante destacar que a pretensão de delegação legislativa do autor ia além do tradicional poder regulamentar próprio do Executivo, já que este era uma "atividade subordinada e restrita" à lei. O que Cavalcanti propunha, ao que parece, era uma delegação legislativa ao Executivo que lhe conferisse certa autonomia no estabelecimento das normas, sobretudo àquelas voltadas à execução da política legislativa.

Cavalcanti admitia a dificuldade constitucional em viabilizar essa "diluição" do poder normativo. Para tanto, trazia à baila a lição no norte-americano Cushman, em obra na qual tratava das comissões reguladoras independentes. Para esse autor, o poder normativo exercido pelos órgãos administrativos não era autenticamente legislativo, possuindo uma natureza própria. Chega a essa conclusão a partir do seguinte silogismo - que mais parece um sofisma - transcrito por Cavalcanti:

Premissa maior - O poder legislativo não pode ser
constitucionalmente delegado pelo Congresso.
Premissa menor - É essencial que alguns poderes
sejam delegados a autoridades administrativas e
comissões independentes.
Conclusão: os poderes delegados não são
legislativos. (apud CAVALCANTI, 1951, p. 448- 
449).

Cavalcanti acrescenta que, se o Congresso tivesse a prerrogativa constitucional de delegar, os poderes conferidos ao Executivo perderiam o caráter legislativo no próprio ato de delegação, tornando-se administrativos ou "quase legislativos". ${ }^{47} \mathrm{O}$ parlamento exerceria seu autêntico poder legislativo fixando os limites e as condições da delegação, ou o que os norteamericanos denominavam como standards normativos.

O jurista se esforça em mostrar que não haveria uma delegação pura e simples do poder soberano de legislar (o que seria inconstitucional). O poder normativo que ele está se esforçando em justificar não é o legislativo e nem o regulamentar, é algo diferente. É um poder "quase legislativo" caracterizando-se como uma função de natureza eminentemente executiva (administrativa) e técnica (ao contrário da "política legislativa" exercida pela lei, que era uma função eminentemente parlamentar). ${ }^{48}$

A partir da obra do norte-americano Harvey Walker, Cavalcanti registrou que " $a$ função política mais importante no terreno do direito administrativo" era justamente a "construção da doutrina do poder normativo na esfera administrativa.", que se justificaria tendo

\footnotetext{
${ }^{47}$ Segundo Cavalcanti, a terminologia "quase legislativo" e "quase judicial" é de "Justice Hugues" quando tratou das "commissions" norte-americanas. (CAVALCANTI, 1958, p. 403). Trata-se do americano Charles Evans Hughes, que durante sua primeira passagem na Suprema Corte (1910 1916) proferiu decisões que ampliaram os poderes regulamentares do Estado, impactando as bases jurídicas do clássico modelo econômico do laissez-faire, mas nas décadas posteriores tendeu a uma postura liberal ortodoxa, opondo-se às políticas do New Deal. Deixou a corte em 10 de Junho de 1916 para ser o candidato republicano à presidência dos Estados Unidos, quando foi derrotado por Woodrow Wilson. Em fevereiro de 1930 se tornou presidente da Suprema Corte, cargo que exerceu até junho de 1941.

${ }^{48}$ É importante destacar que esse "poder normativo" se aproxima daquele poder regulamentar ampliado conferido às corporações de que Roger Bonnard tratava na obra da década de 1930, traduzida e adaptada por Cavalcanti.
}

em vista os problemas técnicos que envolviam a legislação no mundo moderno, forçando "novas demarcações das fronteiras entre os poderes", bem como a definição de uma "zona em comum" em que eles acabavam por se confundir. (1951, p. 449).

\section{CONCLUSÃO}

Se o "olho da lei vigia", aqueles que a criam e a aplicam vigiam o vigilante. ${ }^{49}$

O objetivo deste artigo foi demonstrar como um tema (delegação legislativa e separação de poderes) possui autonomia em relação aos textos constitucionais. Já presente no contexto da Primeira República, a doutrina da delegação legislativa se fortaleceu nos anos 30 e no pós1946 permaneceu mesmo diante de expressa proibição constitucional. Conforme visto, diferentes juristas sustentaram esta doutrina nos diferentes momentos constitucionais, ora a partir e ora apesar da Constituição.

As transformações no direito público parecem ser mais fáceis de ocorrer ao nível do direito administrativo do que do direito constitucional, seja pela "imutabilidade" das cláusulas constitucionais, seja pelo valor político-simbólico das constituições. Ou seja, as "mutações constitucionais" se operam mais facilmente a partir do direito administrativo. Isso ganha maior significado se for levada em consideração a instabilidade constitucional do período vivido pelos autores tratados nesse artigo. Sobretudo no pós-46, parece que a

49 Sobre a história da metáfora do "olho da lei", vide Stolleis, 2006. Para o historiador, o "olho da lei" é uma metáfora moderna, decorrente da secularização e despersonalização de outra metáfora: "o olho de deus". A lei é uma "divindade" secularizada. Ela guarda o passado, mas também se antecipa ao futuro e tudo que há por vir. Nela os homens são iguais. Nela não há pessoalismos. Por meio dela os homens encontram uma crença política dignificante, pois não se curvam aos caprichos de outros homens, mas a uma instituição desencarnada. A respeito do debate sobre do poder de legislar no contexto da formação do Estado Moderno. Vide STOLEIS, 2011. 
máxima de Otto Mayer se inverte, enquanto o direito constitucional permanece formalmente, muitas "reformas constitucionais" se operam por meio do direito administrativo, especialmente na doutrina.

Em síntese, os juristas aqui analisados compartilharam dos seguintes pontos: a) o reconhecimento da emergência histórica de um Estado "moderno" e "interventor"; b) a crença na necessidade de uma legislação técnica e na incapacidade do Legislativo para assumir toda a tarefa legislativa; c) a defesa da ampliação das competências do Executivo, alargando sua atuação no campo normativo; d) a adoção dos conceitos de política legislativa e técnica legislativa; e) o uso dos modelos norteamericanos e ingleses como referenciais; f) a "releitura" de "antigos" conceitos, entre eles a separação de poderes; g) a tolerância quanto às alternativas doutrinárias à margem do texto constitucional; h) a compreensão de que as delegações legislativas não eram em si mecanismos autoritários, eis que poderiam conviver com o regular funcionamento dos parlamentos e funcionar como ferramentas jurídicas adequadas à modernização do aparelho estatal.

Convém destacar que os autores estudados importaram os modelos norte-americanos e ingleses, enfatizando o aspecto das delegações normativas. As delegações de natureza "judicial" foram pouco exploradas por estes juristas brasileiros, tema este que merece futuras reflexões.

Nos anos pós-1930 várias tendências se entrecruzaram. O imaginário de modernização, aliado ao papel indutor do Estado, favoreceram incontáveis transformações no campo jurídico. Entre elas, a crença de que os parlamentos eram casas obsoletas e lentas para enfrentarem as técnicas e rápidas transformações do mundo moderno, como afirmou Themistocles Cavalcanti, o século XIX fora do Legislativo, já o século $\mathrm{XX}$ seria destinado ao Executivo. O tema da intervenção estatal era de natureza técnica, portanto, estranho às contingências políticas do Legislativo e, sobretudo, do "perigoso" universo das democracias de massas.

Isso contribuiu para a formação de uma doutrina pró-delegação legislativa. Um dos caminhos utilizados pelos juristas, mesmo ante a proibição constitucional de delegação, foi a importação/adaptação de modelos norteamericanos e ingleses, tais como o debate acerca das commissions e as regulatory agencies. Porém, no contexto de um país que ainda carecia das mais elementares estruturas burocráticas do Estado moderno, possuía uma prática legislativa incipiente e uma oligarquia disfarçada de república. Enfim, mais um exemplo de "idéias fora do lugar" (Roberto Schwarz).

Mesmo que no início do século $\mathrm{XX}$, sobretudo nas ciências sociais, se constate uma tendência entre os intelectuais brasileiros voltada à superação do "complexo de inferioridade" em relação às teorias criadas nos países cêntricos (LYNCH, 2013), ainda assim, nos meios jurídicos - pelo menos no tema estudado neste trabalho -, nosso "pensamento" permaneceu tributário das "teorias" estrangeiras.

Em grande parte, a história do Direito Administrativo no Brasil pode ser compreendida como um processo de importação de ideias, às vezes sem muita coerência epistemológica ou mesmo política, com vistas a racionalizar conceitos e instituições. Em geral nossos juristas não tinham preocupações cientificas, estavam mais preocupados em oferecer soluções a problemas locais, bem como uma base doutrinal aos projetos de modernização do Estado, quando não estavam, também, disputando espaços de poder e influência. Com isso formou-se uma cultura jurídica administrativa/constitucional fundada em releituras, adaptações e até distorções de modelos estrangeiros. 


\section{REFERÊNCIAS}

ARAGÃO, Alexandre Santos (Org.). O poder normativo das agências reguladoras. 2. ed. Rio de Janeiro: Forense, 2011.

BAQUER, Lorenzo Martín-Retortillo. La configuración jurídica de la administración pública y el concepto de Daseinsvorsorge. In. FORSTOFF, Ernst. Estado de Derecho en mutación. Trabajos constitucionales 1954-1973. Tradução de Patrício Montero-Martín. Madrid: Editorial Tecnos, 2015.

BANDEIRA DE MELLO, Oswaldo Aranha. Princípios gerais de direito administrativo. 3. ed. v. 1. São Paulo: Malheiros, 2007.

BERCOVICI, Gilberto. Estado Intervencionista e Constituição Social no Brasil: O Silêncio Ensurdecedor de um Diálogo entre Ausentes. Disponível em: <http://xa.yimg.com/kq/groups/22789978/2041661191/name/Bercovici>. Acesso em: 21 ago. 2014.

- Instabilidade constitucional e direitos sociais na era Vargas (1930-1964). In. BITTAR, Eduardo (Ed.). História do Direito Brasileiro. São Paulo, Atlas, 2003.

BILAC PINTO, Olavo. Estudos de Direito Público. Rio de Janeiro: Forense, 1953.

BONAVIDES, Paulo; ANDRADE, Paes. História constitucional do Brasil. 5. ed. Brasília: Editora da OAB, 2004.

BURDEAU, Georges. O Estado. Tradução de Maria E. P. Galvão. São Paulo: Martins Fontes, 2005.

BURDEAU, François. Histoire du droit administratif. Paris: PUF, 1995.

CAMPOS, Francisco. O Estado Nacional. Brasília: Senado Federal, 2001.

. Direito Constitucional. Rio de Janeiro: Forense, 1946.

. Direito Administrativo. Rio de Janeiro: Imprensa Nacional, 1943.

. Direito Administrativo. v. I e II. Rio de Janeiro: Livraria Freitas Bastos, 1958.

CASTRO, Alexander; MESURINI, Mauricio da Costa. A racionalidade do direito no Estado Constitucional: uma aproximação entre Max Weber e Luigi Ferrajoli. Trabalho realizado ao longo do mestrado nos anos de 2006 e 2007 (CPGD/UFSC). Ainda inédito.

CAVALCANTI, Themistocles B. Tendências modernas do direito administrativo. Revista Forense. Rio de Janeiro: Fascículo 475, 1943.

1947.

A Constituição de 1946. Revista de Direito Administrativo, Rio de Janeiro, v. VII. Jan/Mar.

. O Estado e a ordem econômica - Problemas de técnica legislativa. Revista de Direito

Administrativo, Rio de Janeiro, v. 25, Jul/Set. 1951 b. 
. A intervenção do Estado e as suas conseqüências na estrutura administrativa. Cinco Estudos. Rio de Janeiro: FGV, 1955.

Teoria do Estado. Rio de Janeiro: Borsoi, 1958.

CODATO, Adriano. Classes dirigentes e fórmula política: afinidades eletivas entre o liberalismo e o autoritarismo no Brasil. Disponível em: $<$ https://www.academia.edu/4114859/Classes_dirigentes_e_f\%C3\%B3rmula_pol\%C3\%ADtica_afini dades_eletivas_entre_o_liberalismo_e_o_autoritarismo_no_Brasil>. Acesso em: 25 jan. 2016.

DINIZ, Eli. Empresário, Estado e Capitalismo no Brasil: 1930-1945. Rio de Janeiro: Paz e Terra, 1978.

DRAIBE, Sônia. Rumos e metamorfoses: um estudo sobre a constituição do Estado e as alternativas da industrialização no Brasil 1930-1946. São Paulo: Paz e Terra, 2004.

ESTORNINHO, Maria João. A fuga para o direito privado: contributo para o estudo da actividade de direito privado da Administração Pública. 2 ed. Coimbra: Almedina, 2009.

FONSECA, Ricardo Marcelo. Introdução teórica à história do direito. Curitiba: Juruá, 2009.

FONTES, Bonifácio. Delegação legislativa. Disponível em: $<$ http://bibliotecadigital.fgv.br/ojs/index.php/rda/article/viewFile/21411/20170>. Acesso em: 10.05.2016.

FORSTHOFF, Ernst. Tratado de Derecho Administrativo. Trad. Legaz Lacambra. Madrid: Instituto de Estudos Políticos, 1958.

Estado de Derecho en mutación. Trabajos constitucionales 1954-1973. Tradução de Patrício Montero-Martín. Madrid: Editorial Tecnos, 2015.

FURTADO, Celso. Formação econômica do Brasil. 11. ed. São Paulo: Editora Nacional, 1971.

GIACOMINI, Charles Jacob. Direito Administrativo comparado - comentários à palestra do juiz federal norte-americano Dr. Peter Messite. Revista da Escola da Magistratura do TRF da $4^{a}$ Região, Porto Alegre, Ano 2, n. ${ }^{\circ}$ 4, 2016.

GRAU, Eros Roberto. O direito posto e o direito pressuposto. 8. ed. São Paulo: Malheiros, 2011.

Comentário o Estado e a ordem econômica segundo Themistocles Cavalcanti, 60 anos depois. Revista dos Tribunais on-line, v. 922/2012, Ago. 2012.

GONÇALVES, Ig Henrique Queiroz. Autocrítica Aristocrática: o conceito de souveraineté du peuple em Alexis de Tocqueville. Dissertação de Mestrado. Programa de Pós-Graduação em Direito. Universidade Federal de Santa Catarina, 2010.

GUANDALINI, Walter. Gênese do Direito Administrativo Brasileiro: formação, conteúdo e função da ciência do direito administrativo durante a construção do Estado no Brasil imperial. Tese (Doutorado em Direito). Programa de pós-graduação em Direito. Universidade Federal do Paraná. 
Curitiba, 2011.

HABERMAS, Jürgen. Técnica e ciência como “ideologia”. Lisboa: Edições 70, 2006.

HESPANHA, António Manuel. Cultura jurídica européia: síntese de um milênio. Florianópolis: Fundação Boiteux, 2005.

O direito administrativo como emergência de um governo activo (c. 1800 - c 1910). Revista de história das ideias. Coimbra: Faculdade de Letras da Universidade de Coimbra, n. 26, 2005.

LOSSO, Tiago. Estado Novo: Discurso, instituições e práticas administrativas. Tese de doutorado em Ciências Sociais. IFCH-Unicamp, 2006.

LYNCH, Christian Edward Cyril. Cultura política brasileira. In: SANTOS, Gustavo; BRITO, Éder (Orgs.). Política no Brasil. São Paulo: Oficina Municipal, 2015.

. Por que Pensamento e não Teoria? A imaginação Político-Social Brasileira e o Fantasma da Condição Periférica (1880-1970). DADOS - Revista de Ciências Sociais. Rio de Janeiro, v. 56, n. ${ }^{\circ}$, 2013.

MÉNARD, René. Mitologia greco-romana. v. 1. Tradução de Aldo Della Nina. São Paulo: Opus, 1991.

METZLER, Edward L. The growth and development of Administrative Law. Marquette Law Review, v. 19, n. 04, 1935. Disponível em: <scholarship.law.marquette.edu/mulr/vol19/iss4/1>. Acesso em: 17 jul. 2015.

NUNES LEAL, Victor. Lei e regulamento. Problemas de Direito Público e outros problemas. v. 1. Ministério da Justiça: Brasília, 1997a.

. Técnica legislativa. Problemas de Direito Público e outros problemas. v. 1. Ministério da Justiça: Brasília, 1997b.

Delegações legislativas. Problemas de Direito Público e outros problemas. v. 1. Ministério da Justiça: Brasília, 1997c.

1955.

. A divisão dos poderes no quadro político da burguesia. Cinco Estudos. FGV: Rio de Janeiro,

PESSOA, Robertônio Santos. Constitucionalismo, Estado e Direito Administrativo no Brasil. Interesse Público, São Paulo: Fórum, n. 53, 2009.

RADBRUCH, Gustav. Introdução à Ciência do Direito. Tradução de Vera Barkow. Martins Fontes: São Paulo, 1999.

SANTOS, Rogério Dultra. Francisco Campos e os fundamentos do constitucionalismo antiliberal no Brasil. Ano 50. v. 002. Rio de Janeiro: IUPERJ, 2007.

SCHMITT, Carl. Interpretación europea de Donoso Cortés. Tradução de Francisco Caballero. Buenos Aires: Struhart \& Cia, 2006. 
SEELAENDER, Airton. CASTRO, Alexander de. Um jurisconsulto adaptável - Francisco Campos (1891-1968). In: MOTA, Carlos Guilherme; SALINAS, Natsha Schmitti Caccia (Orgs.). Os juristas na formação do estado-nação brasileiro: (de 1930 aos dias atuais). São Paulo: Saraiva, 2010.

. Francisco Campos (1891-1968) - uma releitura. In: FONSECA Ricardo Marcelo (Org.). As formas do direito: ordem, razão e decisão. Curitiba: Juruá, 2013.

- O contexto do texto: notas introdutórias à história do direito público na idade moderna. Revista Seqüência, Florianópolis, Pós-Graduação Stricto Sensu em Direito da UFSC, v. 28, n. 55.

SILVA, Ricardo Virgilino da. A ideologia do Estado autoritário no Brasil. Tese de Doutorado. Instituto de Filosofia e Ciências Humanas. Unicamp: Campinas, 1998.

STOLLEIS, Michael. A history of public law in Germany 1914-1945. Tradução Thomas Dunlap. New York: Oxford University Press, 2004.

. Public Law in Germany, 1800-1914. New York: Berghahn Books, 2001.

. L'oeil de la loi. Histoire d'une métaphore. Paris: Mille et une nuits. 2006.

Escribir historia del derecho: ?Reconstrucción, narración o ficción? La historia del derecho como obra de arte. Tradução de Ignácio Gutiérrez Gutiérrez. Granada: Editorial Comares, 2009.

Condere leges et interpretati. Poder legislativo y formación del Estado em la Edade Moderna. La textura histórica de las formas políticas. Tradução de Ignácio Gutiérrez Gutiérrez. Madrid: Marcial Pons, 2011.

SKIDMORE, Thomas E. Brasil: de Getúlio a Castelo (1930-1964). Tradução de Berilo Vargas. São Paulo: Cia. das Letras, 2010.

TOCQUEVILLE, Alexis de. Rapport- Fait a l'académie des sciences morales et politiques (1846), sur le livre de M. Macarel, Intitulé: Cours de Droit administratif. Euvres complètes d'Alexis de Tocqueville. publiées par Mme de Tocqueville [et Gustave de Beaumont], Études économiques, politiques et littéraires - Tome IX. 1866.

TOLMASQUIN, Mauricio T. Novo modelo do setor elétrico brasileiro. Rio de Janeiro: Synergia, 2011.

VENANCIO FILHO, Alberto. A intervenção do Estado no domínio econômico. O direito público econômico no Brasil. Rio de Janeiro: FGV, 1968.

WHITE, Edward G. The constitution and the New Deal. Harvard University Press, 2000.

WOLKMER, Antonio Carlos. Ideologia, Estado e Direito. 4. ed. Revista dos Tribunais: São Paulo, 2003.

Recebido em: 10/03/2016

Aceito em: 19/09/2016 
